\title{
YAPI MALZEMELERINDE KOROZYON VE KOROZYONDAN KORUNMA YÖNTEMLERİ
}

Nazife ÖZER

Alınma: 18.09.2020, düzeltme: 23.11.2020; kabul: 17.07.2021

Öz: Korozyondan birincil derecede etkilenen yapı malzemelerinden olan metaller cephe ve çatı kaplamalarında, taşıyıcı sistemde, kapı ve pencere çerçevelerinde, süslemelerde, betonda donatı çeliği olarak vb. sıklıkla kullanılmaktadır. Bu nedenle metal korozyonun mekanizmasının anlaşılması ve nasıl önlenebileceğinin bilinmesi gerekir. Özellikle atmosferik etkilere açık olan yapı kabuğunda bu konunun önemi artmaktadır. Korozyon olayının yavaş gelişimi nedeniyle göz ardı edilen yapı hasarları yapının bulunduğu ortam şartlarına dikkat edilerek henüz tasarım aşamasındayken uygun malzeme seçimi ve doğru detay tasarımı yapılarak önlenebilir. Özellikle betonarme sistemlerde bazı durumlarda korozyonun oluşması önlemiş olsa dahi gerekli bakım ve onarım yapılmadığında uzun dönemde korozyonun kaçınılmaz olacağı açıktır. Bu çalışmada korozyon mekanizması ve korozyon türleri detaylı olarak anlatılmış ve son bölümde korozyondan korunma yöntemlerinden bahsedilmiştir.

Anahtar Kelimeler: Korozyon, Donatı korozyonu, Metal, Yapı malzemesi

\section{Section Corrosion of Building Materials and Its Prevention}

Abstract: Metals, primarily affected building materials by corrosion, are frequently used in façade and roof coverings, structural system, ornaments, door and window frames, as reinforcing steel in concrete and etc. Therefore, it is critical to prevent corrosion and to understand its mechanism. Moreover, corrosion prove important especially for the building envelope because it is susceptible to atmospheric conditions which lead to building material damages in time. Since corrosion develops slowly, its effects on building materials are usually ignored. However, it can be prevented during the architectural design phase by choosing and applying appropriate materials and detail designs while taking into account environmental conditions. Also, studies show that corrosion can cause devastating damage to metals, and it is inevitable in the long term especially for reinforced concrete systems if periodic maintenance and repair are not carried out. In this study, corrosion mechanism and corrosion types are explained in detail, and lastly, protection methods against corrosion are discussed.

Keywords: Corrosion, Reinforcing Steel, Metal, Building materials

\section{GíRiş}

Korozyon; malzeme ve çevresi arasında, kimyasal ve elektrokimyasal reaksiyonlar sonucu malzeme de oluşan kayıplardır (Çiçek ve AL-Numan, 2012). Yapı malzemelerinin tümü dolaylı veya doğrudan korozyona uğrayabilir. Ancak korozyon özellikle metalleri etkileyen ve yavaş ilerleyen bir yap1 hasarı türüdür. Malzemelerde meydana gelen korozyonun derecesi ortam koşullarına, malzemenin türüne, kimyasal ve elektrokimyasal özelliklere göre değişir (Popov,

\footnotetext{
* İstanbul Teknik Üniversitesi, Mimarlık Fakültesi, Mimarlık Bölümü, 34367, İstanbul. Erzurum Teknik Üniversitesi, Mimarlık Fakültesi, Mimarlık Bölümü, 25050, Erzurum. İletişim Yazarı: Nazife ÖZER (onaln15@itu.edu.tr, nazife.onal@erzurum.edu.tr)
} 
2015). Mimari yapılardaki korozyon hasarı özellikle metal elemanlarda ve betonarme sistemde karşımıza çıkmaktadır.

Metal malzeme korozyondan birincil derecede etkilenmektedir. Dünya genelindeki toplam korozyon maliyetinin 2,5 trilyon dolar olduğu tahmin edilmektedir. Korozyon kontrol uygulamaları ile küresel ölçekte korozyon maliyetinin yıllık \%15-35 arasında azaltılabileceği uzmanlar tarafından tahmin edilmektedir (NACE International, 2016). Buradan anlaşılabileceği üzere metal korozyonundan kaynaklanan malzeme kayıpları ve maddi kayıların büyük kısmı gerekli önlemler alınarak önlenebilir. Korozyon mekanizmasının iyi anlaşılması ile mimari yapılarda alınacak basit önlemlerle korozyonun neden olacağı hasarların önüne geçilebilir.

Çalışmanın amacı, yapılarda metal korozyonunun anlaşılması ve bu hasarların önüne geçilebilmesi için alınabilecek önlemlerin ortaya koyulmasıdır. Bu bağlamda önce, mimari yapılarda metal malzemenin kullanımlarından bahsedilmiştir. Daha sonra korozyon mekanizması ve türleri verilmiştir. Çalışmanın devamında korozyondan korunma yöntemlerinden bahsedilmiştir.

\subsection{Metallerin Mimaride Kullanımı}

Metaller mimari yapılarda taşıdıkları üstün fiziksel ve mekanik özellikler sayesinde eski çağlardan beri kullanılmaktadır. Tarihi yapılarda metal malzeme; strüktürel eleman olarak (kiriş, gergi gibi), kaplama, kenet veya süsleme vb. şekillerde kullanılmıştır. (Zakar ve Eyüpgiller, 2018). Günümüzde ise yapıda strüktürel ve/veya strüktürel olmayan birçok yerde kullanılmaktadır. Örnek olarak cephe ve çatıda kaplama malzemelerinde, taşıyıcı sistemde doğrudan veya betonarme içerisinde donatı elemanlarında, pencere ve kapı doğramalarında, korkuluklarda kullanımları verilebilir. Mimari yapılarda çelik gibi demirli metallerin yanı sıra bakır, alüminyum, çinko, titanyum gibi demir dışı metaller veya bu metallerin alaşımları kullanılmaktadır. Yapıda kullanılan bazı metaller ve bu metallerin özellikleri Tablo 1'de verilmiştir.

Tablo 1. Yapıda kullanılan bazı metaller ve bu metallerin özellikleri (Herzog ve diğ., 2017)

\begin{tabular}{|c|c|c|c|c|c|c|c|c|}
\hline $\begin{array}{l}\text { Metal } \\
\text { Malzeme }\end{array}$ & Alaşım & $\begin{array}{c}\text { Yoğunluk } \\
\text { [gr/cm3] }\end{array}$ & $\begin{array}{r}\text { Elastisite } \\
\text { Modülü } \\
\text { [KN/mm2] }\end{array}$ & $\begin{array}{r}\text { Standart } \\
\text { Potansiyel } \\
\text { [V] }\end{array}$ & $\begin{array}{c}\text { Koruyucu Oksit } \\
\text { Tabakası } \\
\text { Oluşturanlar }\end{array}$ & $\begin{array}{c}\text { Korozyondan } \\
\text { Koruması } \\
\text { Gerekenler }\end{array}$ & $\begin{array}{c}\text { Renk } \\
\text { Değişimi }\end{array}$ & $\begin{array}{l}\text { Akış Halindeki } \\
\text { Su Etkisinde } \\
\text { Renk Değişimi }\end{array}$ \\
\hline Alüminyum & & 2,7 & 65 & $-1,69$ & 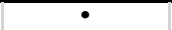 & 0 & $\circ$ & $\circ$ \\
\hline Titanyum & & 4,51 & 110 & & $\bullet$ & $\circ$ & $\circ$ & $\circ$ \\
\hline \multirow[t]{4}{*}{ Demir } & & 7,87 & 210 & 0,44 & $\circ$ & - & - & - \\
\hline & Çelik & 7,8 & 210 & & $\circ$ & $\bullet$ & $\bullet$ & $\bullet$ \\
\hline & Paslanmaz Çelik & 7,98 & 200 & & $\circ$ & $\circ$ & $\circ$ & ${ }^{\circ}$ \\
\hline & \multicolumn{2}{|c|}{ Eskitilmiş Çelik (Korten) } & 200 & & $\bullet$ & $\circ$ & $\bullet$ & $\bullet$ \\
\hline \multirow[t]{3}{*}{ Bakır } & & 8,92 & 132 & 0,35 & $\bullet$ & $\circ$ & $\bullet$ & $\bullet$ \\
\hline & Bronz & 8,73 & 100 & & • & $\circ$ & - & - \\
\hline & Pirinç & 8,5 & 85 & & $\bullet$ & $\circ$ & $\bullet$ & $\bullet$ \\
\hline \multirow[t]{2}{*}{ Çinko } & & 7,2 & 90 & $-0,76$ & $\bullet$ & $\circ$ & $\bullet$ & $\circ$ \\
\hline & Titanyum-Çinko & 7,2 & 80 & & $\bullet$ & $\circ$ & $\bullet$ & $\circ$ \\
\hline Kalay & & 7,29 & 50 & $-0,16$ & $\bullet$ & $\circ$ & $\bullet$ & $\circ$ \\
\hline Altın & & 19,32 & 75 & 1,38 & $\circ$ & $\circ$ & $\circ$ & $\circ$ \\
\hline Kurşun & & 11,34 & 15 & $-0,13$ & - & $\circ$ & - & $\circ$ \\
\hline
\end{tabular}

Yapıda kullanılan çoğu metal türü koruyucu bir oksit tabakası oluştururken demir içerikli metallerin genelinde koruyucu bir oksit tabakası oluşmaz. Oksit tabakasının yoğunluğu ana metalde az olan demir, magnezyum gibi metallerde korozyon lineer hizla devam eder (Kocataşkın, 1979). İstanbul Fener bölgesinde bulunan Stevi Stefan Bulgar Kilisesi (Demir Kilise) 1895-96 yıllarında taşıyıcı sisteminden, kaplamalarına kadar demirden inşa edilmiştir. Cephesindeki demir elemanlarda atmosferik etkilerle oluşan korozyon ve buna bağlı malzeme kayıpları Şekil 1'de açıkça görülmektedir (Zakar ve Eyüpgiller, 2018). Şekil 2'de verilen volta döşeme içindeki demir putrellerin nem etkisinde paslandığı görülmektedir. Paslanma etkisiyle yer 
yer tavan sıvasında dökülmeler, sıvada lekelenmeler ve putrel hizalarında pas izleri görülmektedir.

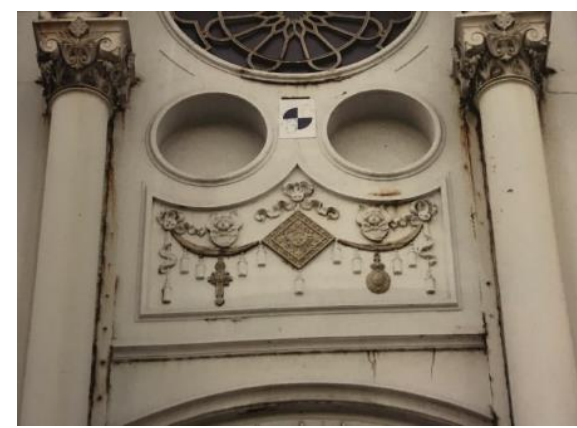

a.

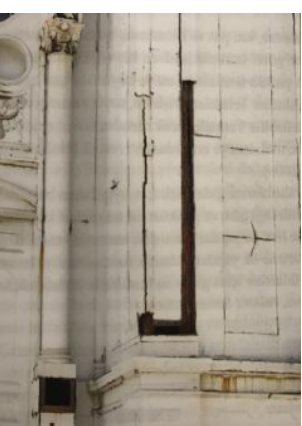

$b$.

Şekil 1:

Stevi Stefan Bulgar Kilisesi, Fatih (İstanbul);

a. Kilise cephesinde oluşan korozyon b. Korozyona bağll metal cephede malzeme kayıpları (Zakar ve Eyüpgiller, 2018)

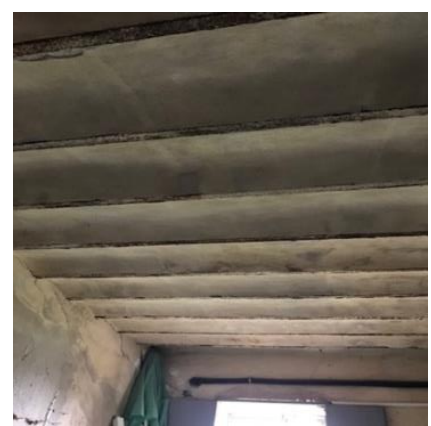

$a$.

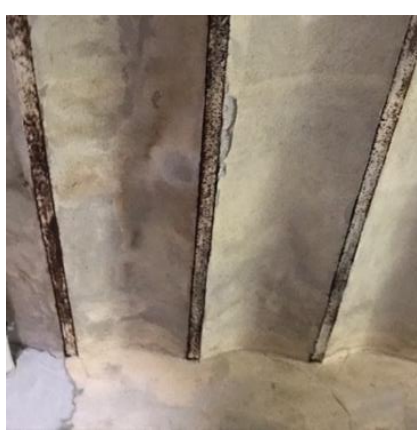

b.

Şekil 2:

Volta döşemede korozyon hasart;

a. Döşemeyi oluşturan demir putreller hizasında oluşan pas lekeleri b. Korozyona bağgl tavan sivasinda dökülmeler ve lekelenmeler

Oksitlenme ile metallerin çoğunda renk değişimi izlenir. En dikkat çekici olanı bakırda meydana gelen renk değişimidir. Mimari yapılarda çatı kaplamasında, yağmur borularında ya da cephe kaplamasında tercih edilen bakır, zamanla oksitlenerek karakteristik yeşil bir renk alır. Demirsiz metallerden olan bakır, havanın oksijeni ve nemini alarak yüzeyinde patina adı verilen bir oksit tabakası meydana getirir. Bu oksit tabakası belirli bir kalınlığa erişince korozyon durur. Bakır havadaki sülfür bileşikleri ile patina tabakasını oluşturur. Bu tabaka özellikle endüstriyel bölgelerde, deniz etkisindeki alanlarda, yüksek sıcaklık veya yüksek nemli bölgelerde daha hızlı oluşur. Bölgeye ve iklime bağlı olarak 5-10 yıl içerisinde bakırın orijinal kırmızı-kahverengi rengi patina tabakası ile yeşile döner (Uffelen, 2015) (Şekil 3).

Metaller özellikle cephelerde kaplama malzemesi olarak sıklıkla kullanılmakla birlikte balkon korkulukları, doğramalar, gölgeleme elemanları, birleşim elemanları, cephe kaplamasını taşıyan elemanlar, süsleme vb. şekillerde de cephede sıklıkla kullanılırlar. Metal cephe kaplamaları; düz metal levhalar, profillendirilmiş metal levhalar, kompozit paneller veya metal örgüler şeklinde uygulanabilmektedir. (Eşsiz ve Ekinci, 2004). Metallerin cephe kaplaması olarak kullanım örnekleri Şekil 4'te verilmiştir. 


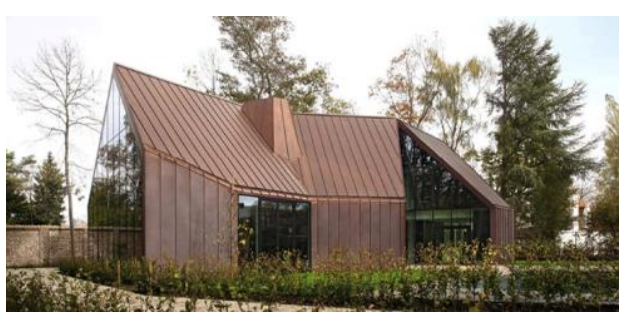

$a$.

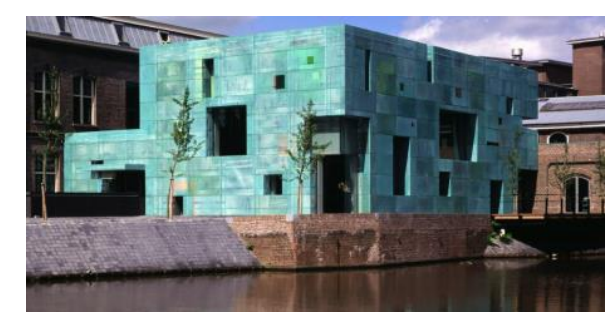

$b$.

\section{Şekil 3:}

Patinalı ve patinasız bakır cephe kaplama uygulama örnekleri;

a. Bakır levha kaplama; House VDV, Destelbergen (Belgium), 2011, Graux \& Baeyens Architecten (https://www.graux-baeyens.be/gba-projects/recent/house-vdv/) b. Patinall perfore baktr düz metal levha kaplama; Sarphatistraat Offices, Amsterdam

(Netherlands), 2000, Steven Holl Architects

(http://www.stevenholl.com/projects/sarphatistraat-offices?)

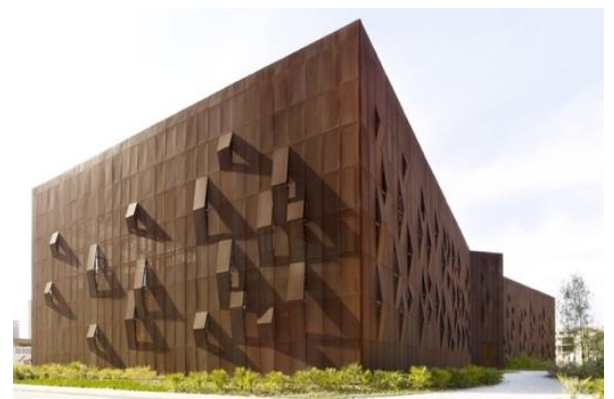

a.

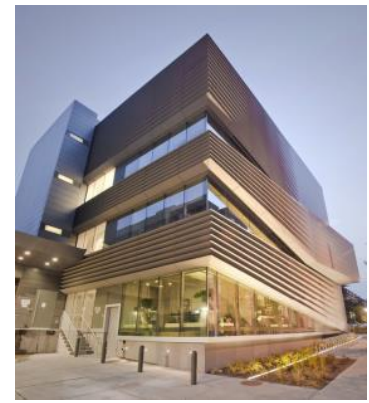

c.

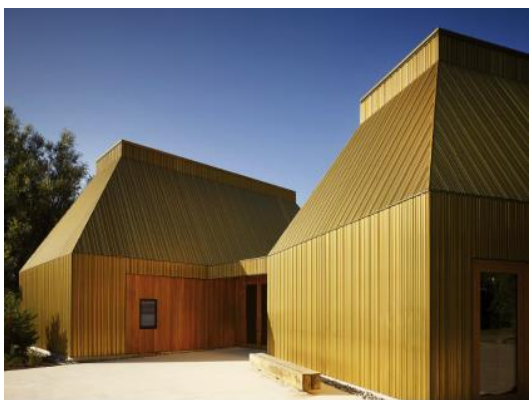

$b$.

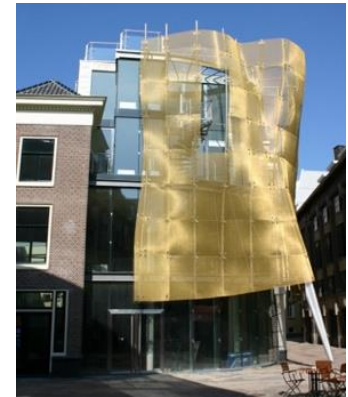

$d$.

Şekil 4:

Metal cephe örnekleri;

b. Eskitilmiş çelik (korten) perfore düz metal levha; Raif Dinçkök Kültür Merkezi, Yalova (Türkiye), 2011, Mimar: Emre Arolat Mimarllk(http://www.kasso.com.tr/projeler/raifdinckok- kultur-merkezi.html) b. Profillendirilmiş pirinç levha; Museum of Art, Ahrenshoop (Germany), Mimar: Volker Staab Architects,( https://www.kme.com/ copper-division/architecture/new-projects/brass/museum-of-art/) c. Polietilen dolgulu çinko kompozit levha; Brown University Granoff Center for Creative Arts, Providence Rhode Island (USA), 2011, Mimar: Diller Scofidio + Renfro,

(https://www.vmzinc.com/) d. Zirkonyum nitrat kapl paslanmaz çelik tel örgü; De Baljurk - Kettingstraat, The Hague (Netherlands), 2005, Mimar: Archipelontwerpers (https://www.archipelontwerpers.nl/en/projects/gown-architectural-transformation-citythe-hague-architect-architectural-office/) 
Metallerin yapıdaki bir diğer yaygın kullanımı betonarme içerisindeki donatı çeliğidir. Beton; çimento, agrega, su ve gerektiğinde katkı maddeleri kullanılarak üretilen taneli bir kompozittir. Beton malzeme çelik çubuklar ile donatılarak betonarme olarak yapıların taşıyıcı sisteminde kullanılır (Şekil 5). Betonarme içerisinde beton malzeme basınca, donatı çeliği eğilmeye çalışan elemanlardır. Betonarme içerisinde kullanılan donatı çelikleri az karbon içeren demir-karbon alaşımlarıdır. Çelik donatılar, beton ve çelik arasındaki aderansı arttıracak şekilde nervürlü olarak üretilir.

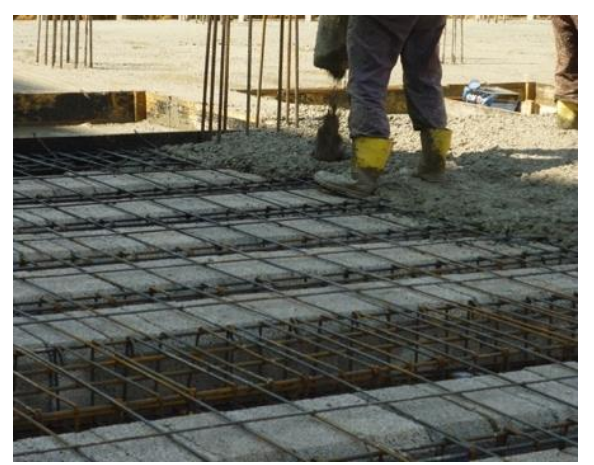

Şekil 5:

Metal malzemenin betonarme içinde donatı çeliği olarak kullanımı

Metaller yukarıda bahsedildiği gibi mimari yapılarda birçok yerde kullanılmaktadır. $\mathrm{Bu}$ nedenle en önemli yapı hasarı türlerinden olan korozyonun oluşum mekanizmasının tasarımcılar tarafından bilinmesi gerekir.

\section{KOROZYON MEKANIZMASI}

Korozyon, çevrenin kimyasal ve elektrokimyasal etkisiyle malzemelerde meydana gelen kayıplardır. Korozyon kimyasal eriyiklerin oluşturduğu doğrudan ve çevre koşullarının oluşturduğu elektrokimyasal olmak üzere iki türlüdür (Onaran, 2014). Elektrokimyasal korozyon özel bir eriyiğe gerek duymadan sürekli oluşur. İnsanların büyük çoğunluğu tarafından demirin paslanması olarak bilinse de korozyon esasen tüm metalleri etkileyen bir olaydır (Roberge, 2012). Seramikler ve polimerler kuvvetli atomsal bağlara sahip ve serbest elektron içermeyen bileşikler olduğundan elektrokimyasal korozyondan etkilenmezken örneğin asitlerin seramikleri ve solventlerin polimerleri tahrip etmesi gibi doğrudan korozyona uğrayabilirler (Onaran, 2014; Aköz ve Çakır, 2014).

Metallerde, havanın nemi ve oksijeni etkisinde oluşan reaksiyonlar ile malzeme yüzeyinde metal oksit film tabakası oluşur. Oluşan bu tabaka normal şartlarda katı haldedir. Ancak oksit tabakasının yoğunluğu ana metalden (ör. Al, Cr, Ni gibi) fazla ise ana metalin hava ile teması azalır ve bu oksit tabakasının kalınlığı arttıkça da korozyon hızı yavaşlar. Ancak Fe, Mg gibi bazı metallerde oluşan oksit tabakası ana metale göre daha boşluklu olduğundan korozyon lineer bir hızla devam eder (Kocataşkın, 1979).

Korozyonun anlaşılabilmesi için metal yüzeyleri etkileyen korozyonun elektrokimyasal doğasının bilinmesi gerekir. Bir elektrolit içine değişik türde iki metal elektrot daldırılır ve bir iletkenle birleştirilirse aralarındaki potansiyel fark nedeniyle birinden diğerine elektron akar (Onaran, 2014). Şekil 6a'da referans hidrojen elektrotuna göre metallerin standart indirgeme potansiyelleri verilmiştir.

Elektrokimyasal reaksiyonlar, elektron alışverişinden meydana gelen anot bölgedeki oksidasyon (yükseltgenme) ve katot bölgedeki redüksiyon (indirgenme) reaksiyonlardır. (Roberge, 2012). Elektron veren metal anot, alan katot sayılır. 


$$
\begin{aligned}
& \text { Anot Bölge } \quad \mathrm{M} \rightarrow \mathrm{Mn}^{+}+\mathrm{ne}^{-} \text {(yükseltgenme reaksiyonu) } \\
& \text { Katot Bölge } \quad \mathrm{Mn}^{+}+\mathrm{ne}^{-} \rightarrow \mathrm{M} \quad \text { (indirgenme reaksiyonu) }
\end{aligned}
$$

Yukarıda (1) ve (2) reaksiyonlarında görüldüğü gibi anottan gelen metal iyonu katot reaksiyonu sonucu katottaki elektrot yüzeyinde birikir ve anot durumdaki metal korozyona uğrar.

\begin{tabular}{|c|c|c|}
\hline \multirow{3}{*}{ Katodik } & $\begin{array}{l}\text { Metal } \\
\text { iyonu }\end{array}$ & $\begin{array}{l}25^{\circ} \mathrm{C} \text { 'de metal iyonlarının } \\
\text { elektrot potansiyelleri }(\mathrm{V})\end{array}$ \\
\hline & $\mathrm{Au}^{3+}$ & 1.50 \\
\hline & $\mathrm{Pt}^{2+}$ & 1.20 \\
\hline \multirow[b]{2}{*}{ Referans } & $\mathrm{Cu}^{2+}$ & 0.34 \\
\hline & $\mathrm{H}^{+}$ & 0.00 \\
\hline \multirow[b]{7}{*}{ Anodik } & $\mathrm{Sn}^{2+}$ & -0.14 \\
\hline & $\mathrm{Ni}^{2+}$ & -0.25 \\
\hline & $\mathrm{Cd}^{2+}$ & -0.40 \\
\hline & $\mathrm{Fe}^{2+}$ & -0.44 \\
\hline & $\mathrm{Zn}^{2+}$ & -0.76 \\
\hline & $\mathrm{Al}^{3+}$ & -1.66 \\
\hline & $\mathrm{Mg}^{2+}$ & -2.36 \\
\hline
\end{tabular}
Böylece "elektrokimyasal pil” ya da "galvani pili" oluşur (Şekil 6b).

$a$.

\section{Sekil 6:}

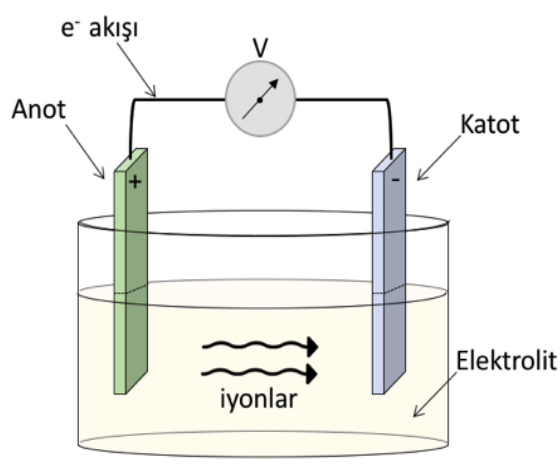

$b$.

a. $25^{\circ} C^{\prime}$ de metal iyonlarınin elektrot potansiyelleri (Popov, 2015) b. Galvani pili (Onaran, 2014)

\subsection{Korozyon Türleri}

Korozyon literatürde çok değişik şekillerde sınıflandırılabilmektedir. Bunlar; galvani pillerinin niteliğine göre (Onaran, 2014); korozyonun görünüşüne göre (NACE, 1984) veya bulunduğu ortamın türüne göre (Yalçın ve Koç, 1991) olabilmektedir (Şekil 7).

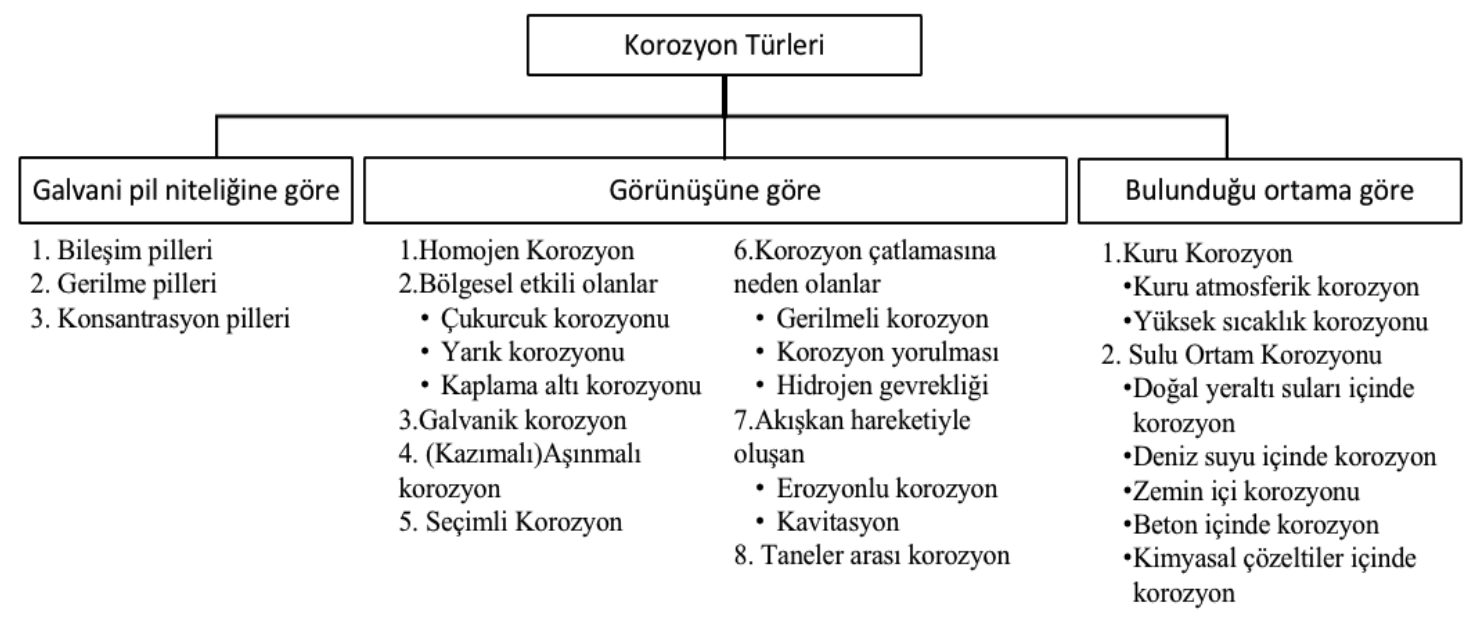

Şekil 7:

Korozyon türlerinin sınıflandırma şekilleri

Korozyon temelde aynı şekilde oluşmuş olsa bile yukarıda verildiği gibi değişik açılardan sınıflandırıp isimlendirilebilir. Çalışma içerisinde görünüşüne göre yapılan korozyon 
sınıflandırmasından kısaca bahsedilmiştir. Ayrıca betonarme içerisinde donatı çeliğinin korozyonuna değinilmiştir.

Korozyon tipleri görünüşlerine göre yapılan sınıflandırmaya göre sekiz ana başlık altında incelenebilir (NACE, 1984). Bu korozyon türlerinin şematik görünümü ve örnekleri Tablo 2'de verilmiştir. Homojen korozyonda metal yüzeyi korozif ortamdan aynı düzeyde etkilenir ve metalin kesit kalınlığı zamanla azalır. Havanın nemi \%70 değerini aştı̆̆ında, metal yüzeyinde görünmez sulu ince bir film tabakası oluşur. Bu film tabakası elektrolit görevi görür ve korozyona neden olur. Ayrıca diğer korozyon türlerinden farklı olarak homojen korozyonda malzemenin ömrü tahmin edilebilir (Fontana ve Greene, 1978). En bilindik örnekler olarak atmosferik korozyon ve çelik ya da çinkonun sülfürik asit içerisinde uğradığg korozyon verilebilir (Jones, 1996).

Homojen korozyon dışında kalan korozyon türleri bölgesel etkilidir ve metal yüzeyinde bir bölgenin ya da yüzeyin küçük bir kısmının korozyona uğraması şeklinde oluşur. Bölgesel korozyon türlerinin en yaygın örneği çukurcuk korozyonudur (NACE, 1984). Bu korozyon türü yüzeyde çeşitli derinlik ve şekillerde çukurlar oluşturur (Tablo 2). Laboratuvar testleriyle anlaşılması güçtür ve oldukça yıkıcıdır. Çukurlar genelde yerçekimi yönünde gelişir (Fontana ve Greene, 1978). Çukurcuk korozyonu genelde bir çözelti içerisinde veya nemli toprakta bulunan metal yüzeylerinde oluşur. Metal yüzeyinde nem damlacıkları veya yoğuşmaya bağlı sulu bir film tabakası bulunuyorsa bu korozyon türü atmosferik ortamda da etkili olur. Genelde çevrenin etkisiyle oluşmuş veya metal yüzeyinde üretim aşamasında oluşturmuş ince film tabakası ile kaplı metallerde görülür. Örneğin; koruyucu film tabakası bulunan magnezyum, alüminyum, titanyum, paslanmaz çelik, bakır gibi... Çukurcuk korozyonu koruyucu tabakanın en zayıf olduğu noktada gelişir (NACE, 1984). Çoğunlukla klorür iyonları çukurcuk korozyonuna neden olur. Şekil 8a'da oksijen içeren $\mathrm{NaCl}$ çözeltisi içindeki $\mathrm{M}$ metali yüzeyinde çukurcuk korozyonu oluşumu verilmiştir. Buna göre metal yüzeyinde oksijenin indirgenme reaksiyonu olurken (4), çukur içerisinde hızlı bir çözünme meydana gelir (3). Bu hızlı çözünme sonucu çukur içerisinde oluşan pozitif bölge, negatif yüklü klorür iyonlarının bu bölgeye geçişini sağlar. Bu durumda çukur içerisinde yüksek konsantrasyonda $\mathrm{MCl}$ bulunur. Çukur içerisinde hidroliz sonucu (5) yüksek konsantrasyonda hidrojen iyonları oluşur. Hidrojen ve klorür iyonları metalin sürekli olarak çözünmesine neden olur. Sonuçta çözeltide oksijen kalmayana dek çukurcuk korozyonu devam eder (Fontana ve Greene, 1978).

$$
\begin{array}{lc}
\text { Metalin oksidasyonu (anot) } & \mathrm{M} \rightarrow \mathrm{M}^{+}+\mathrm{e}^{-} \\
\text {Oksijenin indirgenmesi (katot) } & \mathrm{O}_{2}+\mathrm{H}_{2} \mathrm{O}+4 \mathrm{e}^{-} \rightarrow 4 \mathrm{OH}^{-} \\
\text {Hidroliz } & \mathrm{M}+\left(\mathrm{Cl}^{-}\right)_{2}+2 \mathrm{H}_{2} \mathrm{O} \rightarrow \mathrm{M}(\mathrm{OH})_{2}+2 \mathrm{H}++\mathrm{Cl}^{-}
\end{array}
$$

Aralık korozyonu ya da yarık korozyonu, metal yüzeylerin birleşimlerinde veya metal aparatlarla yapılan montaj noktalarında bulunan boşluk veya yarıklar içerisinde oluşur (NACE, 1984). Metal yüzeyinde kir, toz ve çamur birikintileri aralık korozyonuna neden olabilir (Ahmad, 2006). Oluşum mekanizması çukurcuk korozyonuyla aynıdır (Şekil 8b). Genel olarak 4 aşamada oluşur. Bunlar: aralık içerisindeki çözeltide anot katot reaksiyonları yoluyla oksijenin tüketilmesi ve boşlukta ki metal iyonu konsantrasyonun yükselmesi, metal iyonlarının neden olduğu pozitif yük artışı sonucu $\mathrm{Cl}^{-}$iyonlarının aralık içine toplanması ve $\mathrm{MCl}$ hidrolizi sonucu yüksek konsantrasyonda $\mathrm{H}^{+}$oluşması (bu durumda aralık içinde $\mathrm{pH}$ düşer), düşük $\mathrm{pH}$ sonucu pasif film tabakasının zarar görmesi ve korozyonun metal tükenene kadar devam etmesidir. (Fontana ve Greene, 1978). Genelde alüminyum, magnezyum, paslanmaz çelik ve titanyum gibi oksit film kaplı metal yüzeylerde oluşur. Aralık korozyonu tasarım aşamasında elemanlar arasında ki aralık oluşumu engellenerek veya boşluklar nem direnci yüksek ve esnek bir dolgu ile doldurularak önlenebilir (NACE, 1984). 


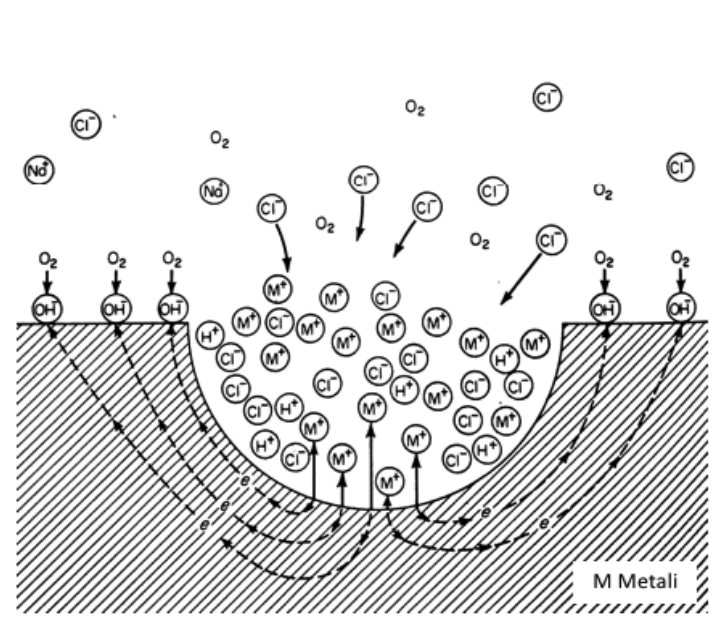

a.

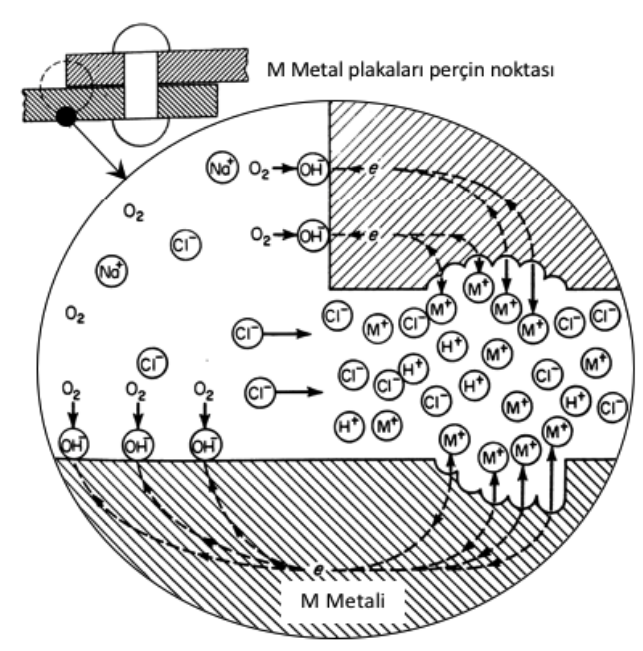

$b$.

Şekil 8:

Oksijen içeren $\mathrm{NaCl}$ çözeltisi içindeki korozyon örnekleri;

a. M metali yüzeyinde çukurcuk korozyonu oluşumu b. M plakaları perçin noktasında aralık korozyonu (Fontana ve Greene, 1978)

Kaplama altı korozyonu, aralık korozyonunun özel bir türüdür. Organik veya metal kaplama bulunan çelik, çinko, alüminyum ve magnezyum ürünlerde kaplamanın hemen altında oluşur (NACE, 1984). Bu tür korozyonda en önemli çevresel faktör atmosferdeki bağım nem değeridir. Kaplama altı korozyonu \%65 değerinden daha düşük bağıl nem değerlerinde oluşmaz. Özellikle \%65-80 bağıl nem aralığında oluşur. Değer \%90'nı aşınca korozyon kabarmalar şeklinde görülür (Fontana ve Greene, 1978). Kaplama altı korozyonunda, korozyon yönündeki anot bölgede oluşan $\mathrm{Fe}^{+2}$ iyonları yoğunluğu sebebiyle, su ozmos ile bu kısımdan kaplama altına girer. Kaplama altından ilerleyerek korozyona uğramış gevşek kısımdan ayrılır (Şekil 9). Düşük oksijen yoğunluğu olan bölge asidiktir ve anottur. Anot bölgeden, oksijen redüksiyonun olduğu katot bölgeye doğru e- akışı olur ve korozyon sürekli olarak devam eder (Fontana ve Greene, 1978).

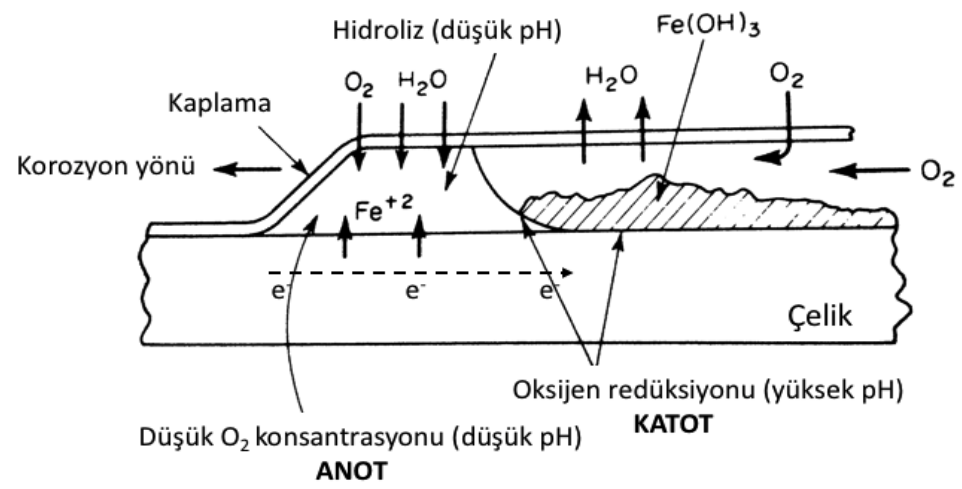

Şekil 9:

Çelik yüzeyde kaplama altı korozyon oluşumu (Fontana ve Greene, 1978)

Galvanik korozyon, galvani pili etkisinde çevre koşulları, elektrolit türü ve konsantrasyonuna bağlı olarak gelişen korozyon türüdür. Galvani pili oluşumundan önceki bölümde detaylı olarak bahsedilmiştir. Standart elektrot potansiyeli farklı iki metalin bir iletkenle veya korozif bir ortamda bir araya geldiği durumda oluşur. Korozyon direnci düşük olan anot durumdaki metal elektron kaybederek korozyona uğrar (Onaran (2014) ve NACE (1984)). Metal parçaları birleştirmek için ana metalden farklı metaller ile yapılmış çivi, vida, perçin vb. 
parçalarda galvani korozyonu oluşabilir (Şekil 10). Bu durumda bu parçaların ana metalle aynı malzemeden yapılması ile galvani korozyonunu önlenebilir (Onaran (2014). Galvani çift oluşturan bu birleşim parçalarında anot durumdaki metal katoda göre daha fazla yüzey alanına sahipse korozyon gerçekleşse bile pratik anlamda önemsiz kabul edilir (Yalçın ve Koç, 1991) (Şekil 11).

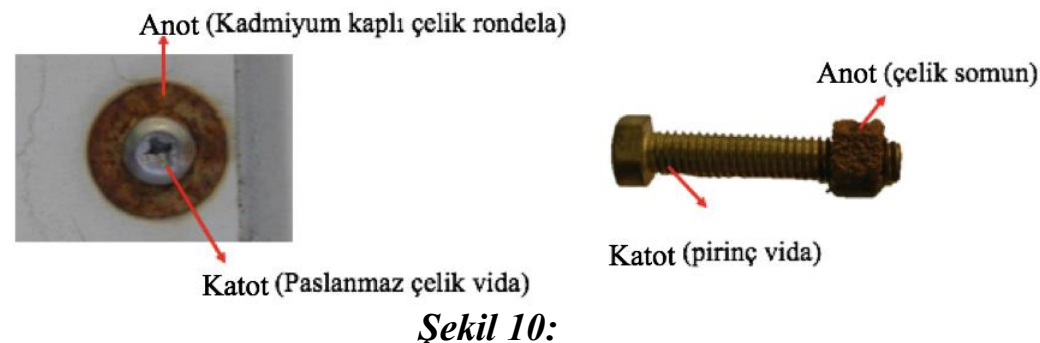

Farklı metallerin yan yana gelmesi ile oluşan galvani korozyon örnekleri

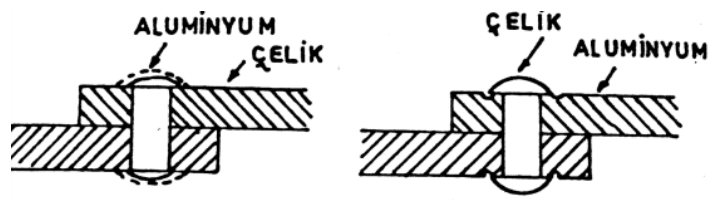

Şekil 11:

Alüminyum ve çelik elemanda katot/anot yüzey alanı etkisi (Yalçın ve Koç, 1991).

Seçimli korozyon, alaşımı oluşturan metallerden aktif olanın diğerinden önce korozyona uğraması sonucu oluşur. En bilindik örneği pirinç içerisindeki çinkonun bakıra göre daha aktif olmasından kaynaklı oluşan korozyondur. Pirinç bu seçimli korozyon sonucu sarı renkten kırmızı bakır rengine döner ve alaşımın mukavemeti azalır (Jones, 1996). Kazımalı (aşınmalı) korozyon, yük altında birbiri üzerinde hareket eden yüzeyler arasında oluşur. Korozyon çukur ve çizgisel boşlukları dolduran korozyon ürünleri şeklinde görülür. Genelde makine parçaları bu kazımalı korozyona uğrar. Taneler arası korozyon; metal malzemenin tane sinırlarında meydana gelir. Malzemede mukavemet ve süneklik kaybına neden olur (NACE, 1984). Korozyon tane sınırlarında ilerledikçe tane sınırları zamanla zayıflar ve sonunda parçalanır (Ahmad, 2006). Özellikle alüminyum, bakır ve 18-8 paslanmaz çelik alaşımları taneler arası korozyondan etkilenir (NACE, 1984).

Korozyon çatlamasına neden olan üç tip korozyon vardır: gerilmeli korozyon, hidrojen gevrekliği ve korozyon yorulması. Gerilmeli korozyon, çekme gerilmeleri ve kimyasal etki altında metal malzemede meydana gelen korozyon türüdür. Malzeme yüzeyindeki mevcut çatlaklar ve düzensizlikler nedeniyle başlar (NACE, 1984). Zaman içerisinde hızla ilerleyerek malzemede taşıma gücü altındaki değerlerde ani kopmalara neden olabilir. Bu nedenle önemli bir korozyon çeşididir. Metale, bulunduğu ortama ve gerilme düzeyine göre birkaç dakikadan birkaç yıla kadar geçen sürelerde oluşabilir (Revie ve Uhlig, 2008). Korozyon yorulması, yük ve korozyonun birleşik etkisinde tekrarlayan gerilmelerle metal malzemede düşük yük seviyelerinde meydana gelen kırılmalardır. Korozif ortam etkisinde daha hızlı gerçekleşir. Metal yüzeyinde zayıf noktalarda başlar ve ilerler. Örneğin; çukurcuk veya taneler arası korozyon oluşmuş bölgelerde oluşabilir (Ahmad, 2006). Genelde ana çatlak etrafinda metal yüzeyinde çatlaklar oluşur ancak kırılma ana çatlakta gerçekleşir (Revie ve Uhlig, 2008). Hidrojen gevrekliği, hidrojen gazı ile temas halindeki alaşımların plastik deformasyonu sırasında meydana gelir ve yükleme hızına bağlıdır. Gerilme korozyonu malzeme yüzeyinde başlarken hidrojen gevrekliği malzemenin içinde başlar (Ahmad, 2006) (Tablo 2). 
Tablo 2. Görünüşüne göre korozyon türlerinin şematik gösterimleri ve örnekleri

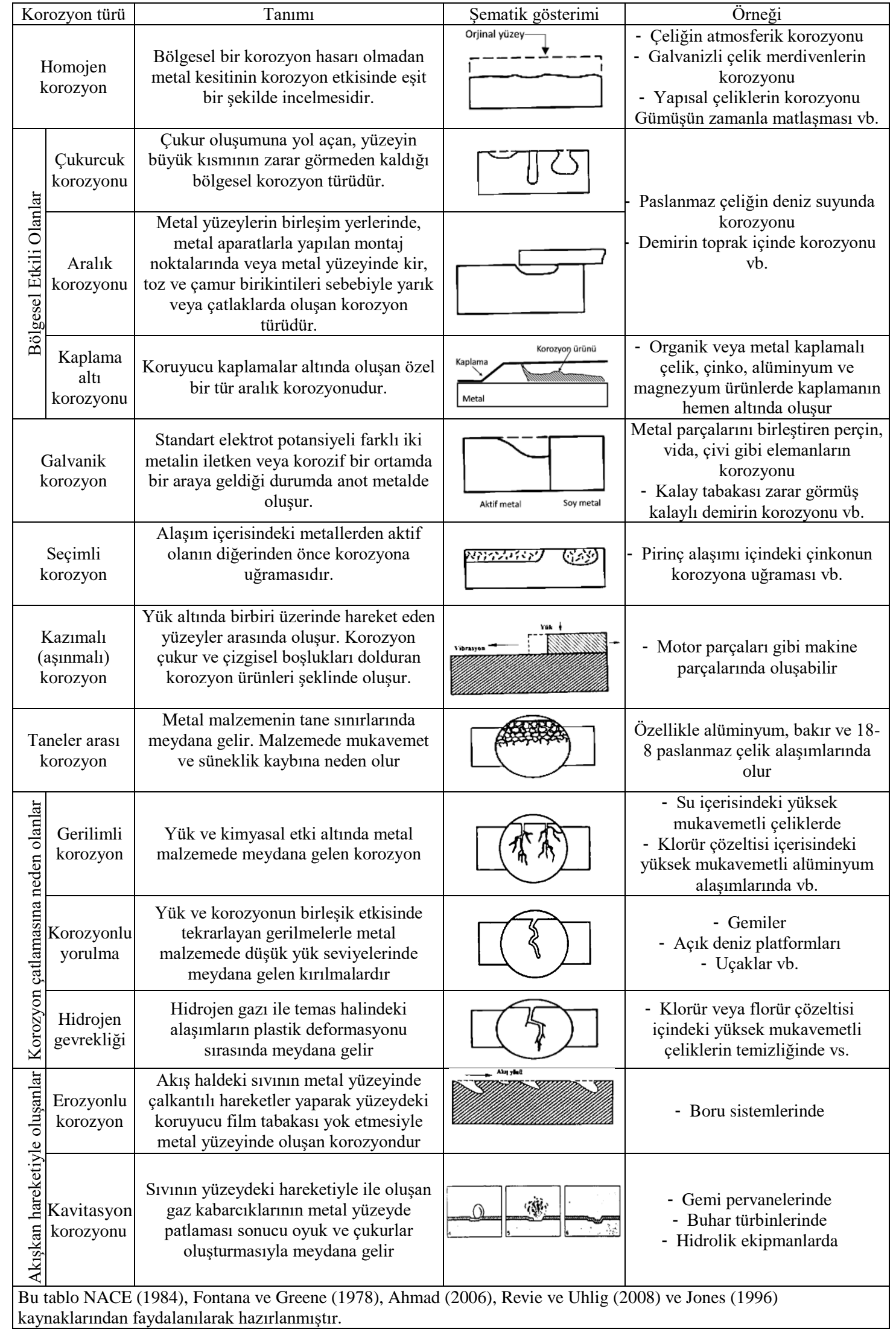


Akışkan hareketleriyle oluşan korozyon türleri metal yüzeyinde mekanik bir hasara neden olur. Erozyonlu korozyon, akış haldeki sıvı metal yüzeyinde çalkantılı hareketler yaparak yüzeydeki koruyucu film tabakası yok eder ve metal yüzeyinde korozyona neden olur. Bu tür korozyonda homojen yayılımlı bir hasar olabileceği gibi sıklıkla yüzeyde çukurlaşmış bölgeler oluşur (NACE, 1984). Bakır, kurşun gibi yumuşak metaller erozyonlu korozyona daha duyarlıdır. Hareketli sivilara maruz kalan boru sistemleri bu korozyondan etkilenir (Fontana ve Greene, 1978). Kavitasyon korozyonu ise erozyonlu korozyonun özel bir türüdür. Sıvının metal yüzeyindeki hareketiyle ile oluşan gaz kabarcıklarının yüzeyde patlaması sonucu oyuk ve çukurlar oluşturmasıyla meydana gelir. Gemi pervaneleri gibi hızlı sıvı akışının olduğu yerlerde görülür (NACE, 1984).

\subsection{Betonarme Sistemde Kullanılan Donatının Korozyonu}

Beton; çimento, agregalar ve genelde çeşitli katkılardan oluşan bir kompozittir. Beton içerisindeki Portland çimentosu kalsiyum silikat ve kalsiyum alüminalardan oluşur. Su ve agregalar ile karıştırıldığında işlenebilir bir karışım olan taze beton priz aldıktan sonra hidrate bileşikler içeren yüksek basınç dayanımı ve düşük çekme dayanımı olan sert bir malzeme oluşturur. Betonun düşük çekme dayanımının iyileştirilmesi için düşük karbon içeren donatı çelikleri ile donatılarak taşıyıcı sistemde kullanılır.

Çimento içerisindeki klinker bileşiklerinin su ile reaksiyonu sonucu kuvvetli bazik karakterde olan kalsiyum hidroksit meydana gelir. Normal betonda $\mathrm{pH}$ derecesi 12-13 civarında olur. Yüksek $\mathrm{pH}$ derecesi kısa sürede donatı çeliği yüzeyinde kararlı ve koruyucu bir oksit tabakası $\left(\mathrm{Fe}(\mathrm{OH})_{3}\right)$ oluşturur. Bu durum korozyona dayanıklılığ düşük olan çelikte anodik akım yoğunluğunu kısıtlayarak metalin pasifleşmesini sağlar (Yalçın ve Koç, 1991). Pasifleşen donatının çevresi ile teması kesilir ve korozyon durur. Normal betonda bu oksit film tabakası bozulmadan uzun süre çeliğin korozyonu önler (Yalçın ve Koç, 1997; Aköz ve Çakır, 2014). Pasif oksit tabakanın yok olması ya da kısmen etkisizleşmesi ile donatı korozyonu başlayabilir. Koruyucu pasif tabaka şu şekillerde tahrip olur (Hunkeler, 2005):

- Betonun karbonasyonu

- Klorür etkisi

Betonda oluşan bir çatlak donatı üzerinde çatlak etrafındaki alanda pasif tabakanın kısmen bozulması durumda yerel korozyon oluşumundan bahsedilebilir ya da gözenekli bir betonda karbonatlaşma nedeniyle pasif tabakanın bozulması daha geniş alanda etkili olması durumunda homojen korozyondan bahsedilebilir (Bentur ve ark., 2011). Bu tabaka betonun geçirimli olmas1, ortamda su ve oksijen bulunması, beton üretiminde $\mathrm{Cl}$ iyonu içeren agregaların veya katkıların kullanılması, karbonatlaşma gibi birçok nedenle tahrip olabilir (Aköz ve Çakır, 2014). Korozyon bir kez başladığında sürekliliği özellikle katodik bölgede oksijenin varlığı ve donat1 yüzeyine komşu beton boşlukları içerisindeki suyun varlığına bağlı olarak devam eder. Pasif tabakanın tahrip olmasını takip eden süreçte aktif korozyon oluşumu gözlenir. Şekil 12'de verildiği gibi aktif dönemde (yayılma dönemi) korozyon oluşumu sabit bir rejimde olmaz (Bentur ve ark., 2011). Ortamdaki oksijen varlığına, sıcaklığa, betonun nem içeriğine, beton kalitesine, betonun elektriksel direncine ve beton gözeneklerindeki suyun $\mathrm{pH}$ değerine bağli olarak değişir (Hunkeler, 2005, Tuutti, 1982).

Donatı yüzeyinde oluşan korozyon ürünü kütlece çok az kayba neden olsa da hacmi 1-6 kat kadar artar. Donatıdaki hacim artışı betonda çekme gerilmeleri oluşturur. Bu gerilmeler, çekme dayanımı ve çekmede uzama oranı çok düşük ve gevrek bir malzeme olan betonda donatıya paralel çatlaklar oluşturur. İlerleyen süreçte kapak atmalar görülür, örtü betonu kütleden ayrilır ve donatı açığa çıkar (Şekil 13) (Şekil 14) (Yalçın ve Koç, 1997; Aköz ve Çakır, 2014). 


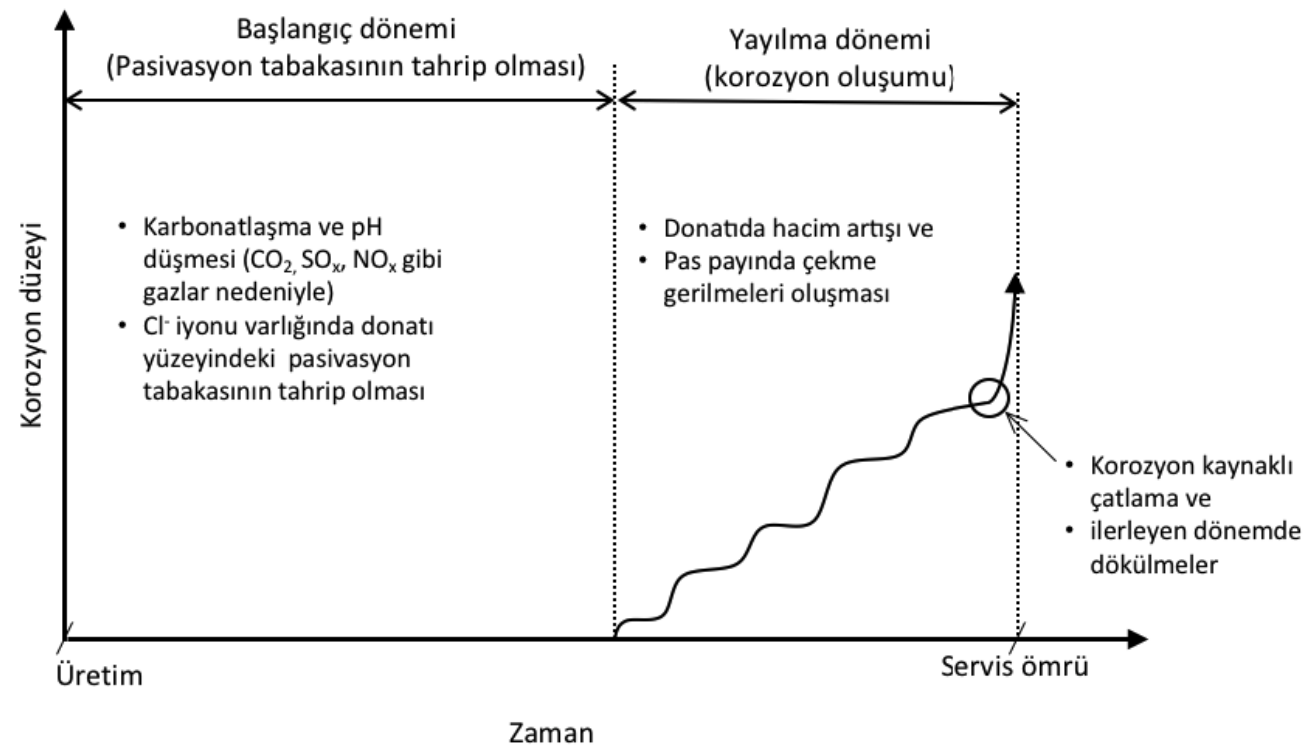

Şekil 12:

Beton içerisindeki donatının korozyon modeli (Bentur ve ark., 2011; Hunkeler, 2005)

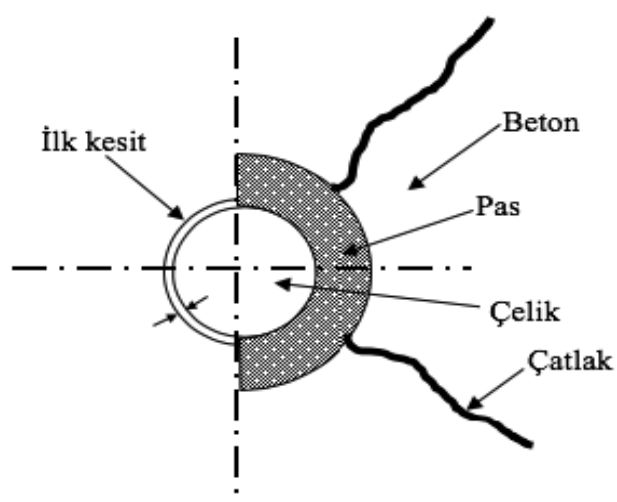

a.
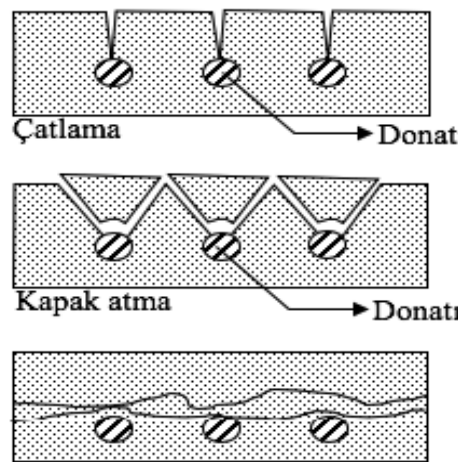

Paspayı tabakasının tabaka halinde ayrișması

Şekil 13:

a. Korozyon sonucu donatıda meydana gelen hacim artışı b. Donatıdaki hacim artışının betona etkileri (Aköz ve Çakır, 2014)
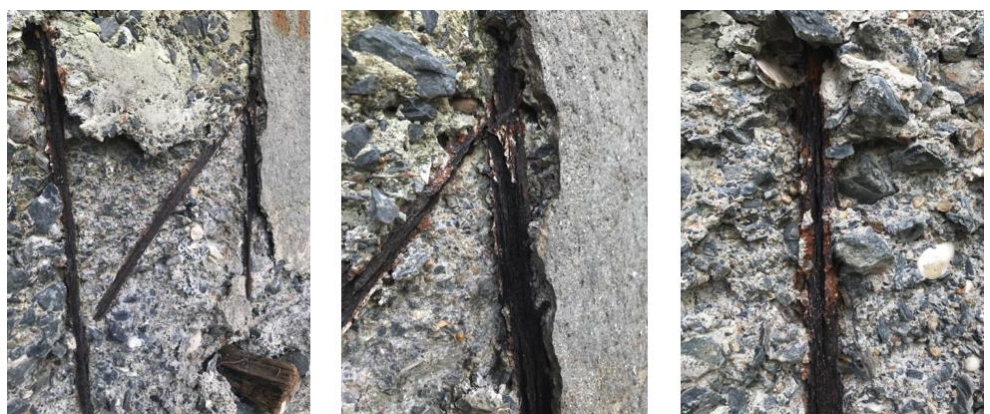

Şekil 14:

Beton içerisinde korozyona uğrayan donatı 
Betonarme içerisinde bulunan çözünmüş klorür korozyon hasarında önemli rol oynar. Klorür betonarmeye karışım suyuyla, agregalarla veya karışım suyuna erken priz için katılan katkılar ile girmiş olabilir. Ayrıca deniz yakın bölgelerde deniz etkisiyle ya da kara yollarında kar ve buzlanmaya karşı yapılan tuzlama ile klorür çatlak ve boşluklardan beton içerisine girebilir (Jones 1996). Beton içine başlangıçta döküm sırasında girmiş olan klorür ile, sonradan sertleşmiş beton bünyesine çevreden giren klorür iyonlarının etkisi farklıdır. Beton içerisinde çimento ağırlığına oranına göre $\mathrm{Cl}$ iyon miktarının artışı korozyon riskini arttırır. Beton henüz priz almadan karışımdaki $\mathrm{Cl}$ iyonlarının bir kısmı klinker bileşenleriyle suda çözünmeyen tuzlar oluşturur. $\mathrm{Bu}$ şekilde kimyasal olarak bağlanmış klor artık korozyon açısından etkili değilken serbest haldeki klorür iyonları betonarme yapıda ciddi hasarlara neden olur. Çünkü beton içerisinde $\mathrm{Cl}$ iyonları anodik bölgede, çelik üzerindeki koruyucu pasif tabakayı tahrip eden hidroklorik aside dönüşür ve korozyona neden olur (Aköz ve Çakır, 2014; Yalçın ve Koç, 1997). Klorür etkisinde donatıda çukurcuk korozyonu meydana gelebilir (Yalçın ve Koç, 1991) (Şekil 15).

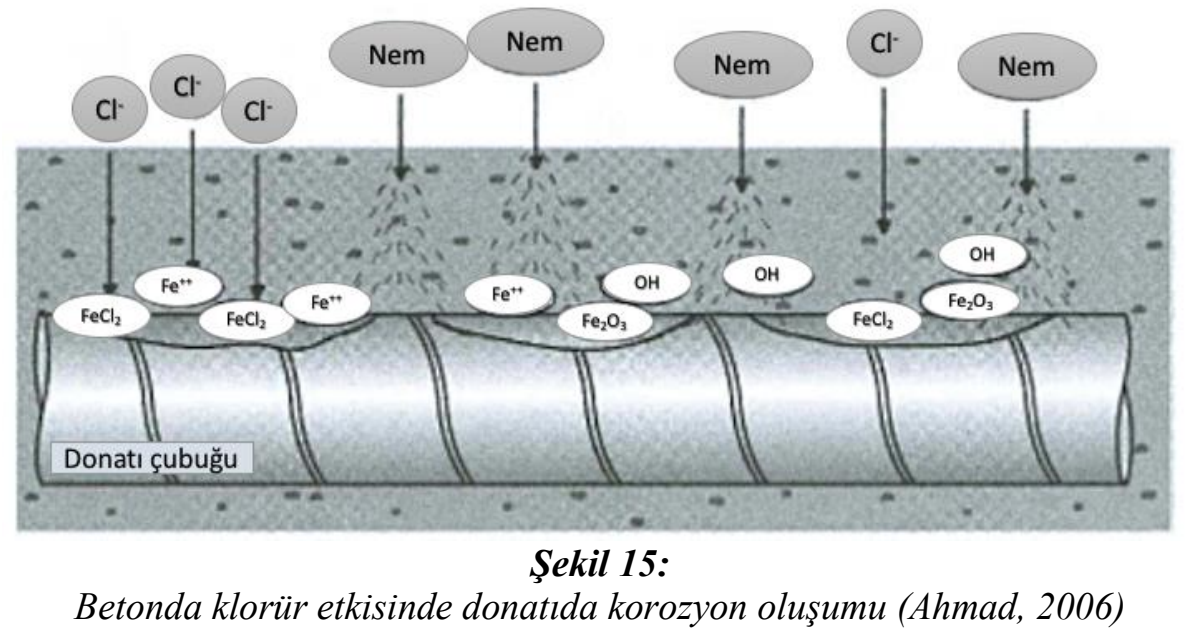

Klorür etkisinde donatı korozyonu şu şekilde gelişir; betona giren klorür iyonları koruyucu oksit tabakası tarafından absorbe edilir, anot bölgede $\mathrm{Fe}^{2+}$ iyonları $\mathrm{Cl}^{-}$iyonları ile $\mathrm{FeCl}_{2}$ şeklinde çözelti oluşturur (6)(7). $\mathrm{Bu} \mathrm{FeCl}_{2}$ su ile tepkimeye girerek $\mathrm{Fe}(\mathrm{OH})_{2}$ oluşturur (8). Bu reaksiyon sonucu ayrıca ortamda $\mathrm{H}^{+}$ve $\mathrm{Cl}^{-}$iyonları oluşur. $\mathrm{Fe}^{2+}$ iyonlarının $\mathrm{Cl}^{-}$iyonları ile reaksiyonunu, $\mathrm{Fe}$ $(\mathrm{OH})_{2}$ oluşumunu ve $\mathrm{H}^{+}$ile $\mathrm{Cl}^{-}$iyonlarının salınmasını içeren reaksiyon döngüsü koruyucu $\mathrm{Fe}_{2} \mathrm{O}_{3}$ veya $\mathrm{Fe}_{3} \mathrm{O}_{4}$ tabakas1 tamamen yok olana kadar devam eder (Ahmad, 2006). Beton $\mathrm{pH}$ derecesi yüksek olduğundan katot reaksiyonu daima (9)'da verildiği gibi oksijen redüksiyonu şeklinde oluşur (Yalçın ve Koç, 1991).

Donatının oksidasyonu (anot)

$$
\mathrm{Fe} \rightarrow \mathrm{Fe}^{+2}+2 \mathrm{e}^{-}
$$

$$
\mathrm{Fe}^{2}++4 \mathrm{Cl}^{-} \rightarrow \mathrm{Fe}\left(\mathrm{Cl}_{4}\right)^{-2}+2 \mathrm{e}^{-}
$$

$$
\mathrm{Fe}\left(\mathrm{Cl}_{4}\right)^{-2}+2 \mathrm{H}_{2} \mathrm{O} \rightarrow \mathrm{Fe}(\mathrm{OH})_{2}+2 \mathrm{H}^{+}+4 \mathrm{Cl}^{-}
$$

$$
\text { Oksijen redüksiyonu (katot) } \quad 1 / 2 \mathrm{O}_{2}+\mathrm{H}_{2} \mathrm{O}+2 \mathrm{e}^{-} \rightarrow 2 \mathrm{OH}^{-}
$$

Betonun sertleşmesi sırasında klinker bileşenlerinin hidratasyonu sonucu oluşan kalsiyum hidroksit, zamanla atmosferde bulunan karbondioksitin beton içine girmesiyle kalsiyum karbonata dönüşür (Tuutti, 1982). Bu olaya karbonatlaşma adı verilir. Birçok gaz gibi karbondioksitte suda çözünür ve karbonik asiti $\left(\mathrm{H}_{2} \mathrm{CO}_{3}\right)$ oluşturur (10). Bu asit betona zarar vermez ancak beton boşluk suyundaki alkalinleri nötrleştirir (11). Bu durumda betonun $\mathrm{pH}$ değeri 
8 civarına düşer (Bentur ve ark., 2011; Broomfield,1997). Karbonatlaşma şu şekilde oluşur (Broomfield,1997):

$$
\begin{aligned}
\mathrm{CO}_{2}(\mathrm{gaz})+\mathrm{H}_{2} \mathrm{O}(\mathrm{su}) & \rightarrow \mathrm{H}_{2} \mathrm{CO}_{3} \text { (karbonik asit) } \\
\mathrm{H}_{2} \mathrm{CO}_{3}+\mathrm{Ca}(\mathrm{OH})_{2} & \rightarrow \mathrm{CaCO}_{3}+\mathrm{H}_{2} \mathrm{O}
\end{aligned}
$$

Karbondioksitin betona difüzyonu atmosferdeki $\mathrm{CO}_{2}$ 'in kısmî basıncına ve betonun gözenek yapısına bağlı olarak değişir. $\mathrm{CO}_{2}$ 'in kısmî basıncı genelde sabit kabul edilir ancak endüstriyel bölgelerde normalden yüksek olabilir. Beton paspayı yeterli kalınlıkta olması durumunda karbonatlaşma betonun servis ömrü boyunca donatı yüzeyine ulaşamaz (Bentur ve ark., 2011). Benzer olarak kirli atmosferde bulunan $\mathrm{SO}_{x}$ ve $\mathrm{NO}_{x}$ gibi asit anhidriti olan gazlarda kalsiyum hidroksitle reaksiyona girerek $\mathrm{pH}$ derecesini düşürebilir. Alkalitenin düşmesi çelik üzerindeki koruyucu pasif tabakayı tahrip eder ve korozyona neden olur (Yalçın ve Koç, 1997). Karbonatlaşma genelde eski yapılarda izlenir. Karbonasyonun belirlenmesi ve ölçülmesi kolaydır. Ölçüm için pH göstergesi olarak su veya alkol çözeltisi içindeki fenolftalein bileşimi kesit yüzeyine sürülür. Kimyasal sürülen yüzeyde $\mathrm{pH}$ değeri düşük yüzeyde (karbonatlaşmış) renk izlenmezken, pH değeri yüksek bölgede pembe renk izlenir (Broomfield,1997).

\section{KOROZYONDAN KORUNMA YÖNTEMLERİ}

Elektrokimyasal bir korozyon hücresi dört ana unsurdan oluşur. Bunlar Şekil 16'da verildiği gibi yükseltgenme reaksiyonu sonucu elektron kaybının olduğu anot, indirgenme reaksiyonu sonucu elektron kazancı olan katot, anot ve katodun içinde bulunduğu çözeltinin oluşturduğu iyonik akım yolu ve onları bir iletken ile bağlayan bir e- akım yoludur. Bu dört unsurdan birinin olmaması durumunda korozyon oluşmaz ve durur. Örneğin; anot metali ortamdan uzaklaştırmak ya da anot metali inaktif hale getirmek yöntemleri ile korozyon önlenebilir. Bunun dışında iyonik akım yolunun engellenmesi ya da ortadan kaldırılması ile korozyon önlenebilir. Örneğin metalin bulunduğu ortamda nem elektrolit olarak görev yapacağından, nemin olmadığı durumda iyonik akım yolu oluşmayacak ve korozyon engellenecektir. Standart elektrot potansiyelleri farklı iki metalin bir arada kullanılması ile oluşan galvanik korozyonda metallerin birleşim yerine yerleştirilecek ayırıcı katmanlar ile elektriksel olarak yalıtılmış olacağından korozyon önlenmiş olur. Bunların dişında en etkili korozyon kontrolü yöntemlerinden biriside katodun varlı̆̆ının engellenmesidir. (Davis, 2000)

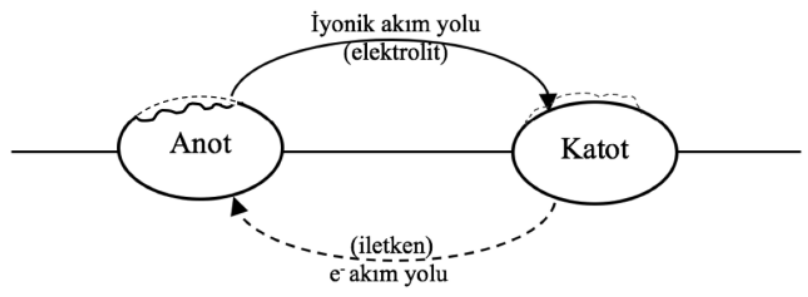

Şekil 16:

Elektrokimyasal korozyon hücresini oluşumu şeması (Davis, 2000)

\subsection{Metal Korozyonundan Korunma Yöntemleri}

Korozyondan korunma yöntemleri 4 ana başlık altında Şekil 17'de verildiği gibi gruplandırılabilir. 


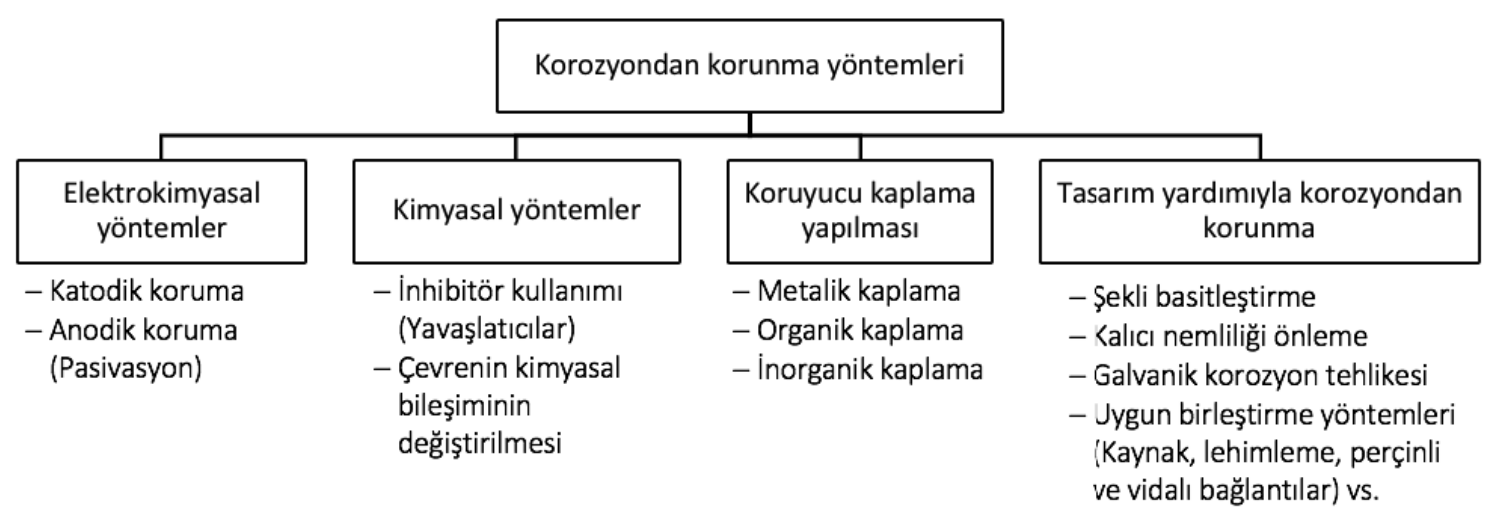

Sekil 17:

Korozyondan korunma yöntemleri

Korozyondan korunma yöntemlerinden endüstride en yaygın kullanılan yöntem katodik korumadır. Anottan katoda doğru olan elektron akışının engellenmesi için, dışarıdan bir kaynakla katoda akım verilmesi yoluyla koruma gerçekleşir (Revie ve Uhlig, 2008). Katodik korumada Şekil 18'de verildiği gibi kullanılabilecek iki yöntem vardır. Bunlardan ilki aynı elektrolit içine anot görevi yapacak ana metalden daha aktif bir metalin daldırılmasıdır. Bu bir çeşit büyük ölçekli galvani pil oluşturur ve katodu korur. İkinci yöntem ise; inert bir anot kullanıp sisteme dıştan bir doğru akım uygulanması şeklindedir (Yalçın ve Koç (1997), Revie ve Uhlig (2008)). Bu koruma sistemi endüstride geniş ölçüde kullanılır. Başta yeraltı boru hatları, elektrolit içinde bulunan (su, toprak, beton vb. ) bütün metalik yapılarda tercih edilir.

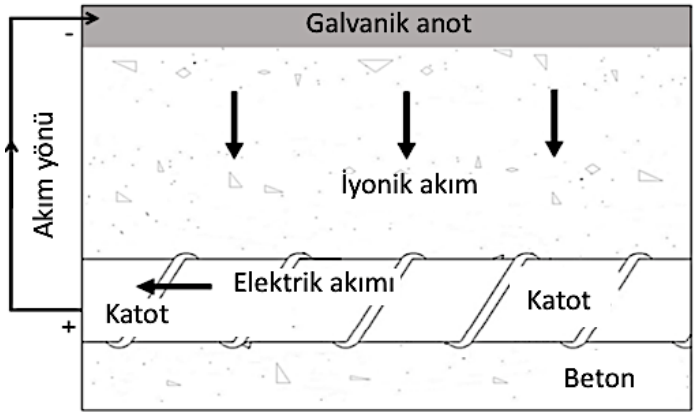

$a$.

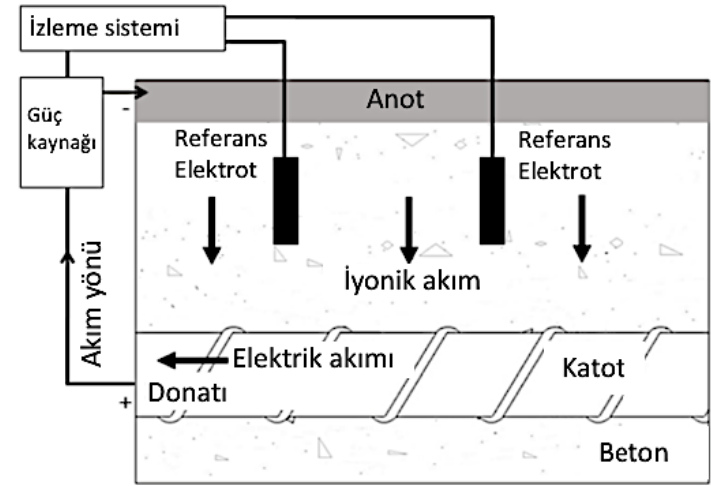

b.

Şekil 18:

Betonarme sistemde katodik koruma (Nadzri ve Amin, 2019); a. Galvanik anotlu katodik koruma b. Dış akım kaynaklı katodik koruma

Galvanik anotlu katodik koruma sistemi doğru akım kaynaklı sisteme göre tasarımı ve uygulanması daha kolaydır, dış akım kaynağı ve bir kontrol sistemi gerektirmez (Nadzri ve Amin, 2019). Ancak galvanik anotlu sistemin akım maliyeti daha yüksek olduğundan dış akım kaynaklı sistem yüksek akım gerektiren uygulamalarda daha sık tercih edilir (Yalçın ve Koç, 1991). Beton yüksek direnç ortamı olduğundan dış akım kaynaklı katodik koruma sistemi daha uygundur. Ancak bu sistem gereği sürekli olarak doğru akım kaynağı gerekir (Nadzri ve Amin, 2019).

Elektrokimyasal korunma yöntemlerinden diğeri anodik korumadır. Galvani serisine göre anot yönde olan metaller aktif anot reaksiyonu gösterir. Anodik koruma metale dişardan verilen anodik bir akım ile metal yüzeyinde koruyucu bir film tabakası oluşturulması ile sağlanır (Fontana 
ve Greene, 1978). Pasivasyon denilen bu olay metalleri korozyona karşı önemli ölçüde korur. Ancak çok az sayıda metal belli çözeltiler içinde pasifleşme özelliği gösterir. Yumuşak çelikler sülfürik asitle, paslanmaz çelik fosforik asitle, nikel nitrik asitle ve titanyum amonyak organik asitler ve kostik çözeltileri ile anodik koruma uygulanır (Yalçın ve Koç, 1997). Genelde çelik sülfürik asit tankları gibi çok korozif ortamlarda kullanılan bir yöntemdir. Katodik koruma gibi tüm metallerde uygulanamaz ve katodik korumaya göre daha pahalı ve uygulanması daha zordur (Fontana ve Greene, 1978).

Tasarım aşamasında alınacak önlemler ile korozyonun önüne geçilebilir. Tasarımda mümkün olduğunca az birleşim gereken tek parça ürünlerin kullanımı, tasarımın mümkün olduğunca nemden korunması, birleşim bölgelerinde (bulon, vida, perçin, kaynak vb.) mümkün olduğunca dar açıklıklardan kaçınmak gibi basit prensipler ile korozyon oluşumu önlenir. Farklı iki metalin bir arada kullanıldığı birleşimlerde galvani korozyondan (birleşim pili) kaçınılmalıdır. Galvanik etkenin oluşmaması için metaller arasında yeterli potansiyel fark olmalıdır veya birbirleri ile doğrudan temas etmemelidir (Kaftan, 2006). Korozyon hızını çevrenin kimyasının değiştirilmesi ile azaltmanın etkin yolları ortamın sıcaklığı, akma hızı, konsantrasyonu, içerdiği oksijen ve diğer oksitleyicilerin miktarıdır. Örneğin; su arıtılması veya hava rutubetinin giderilmesi gibi (Yalçın ve Koç (1997); Fontana ve Greene (1978)).

Korozyondan korunmada kimyasal yöntem olan inhibitörler, düşük konsantrasyonda ve agresif ortamda bulunan korozyonu engelleyen veya en aza indiren maddeler veya karışımlardır. İnhibitörler şu şekilde koruma sağlayabilir: metal yüzeyiyle etkileşime girip metali pasifleştirmek ya da ortamdaki sulu aşındırıcı bileşenle reaksiyona girerek koruma sağlamak (Tuutti (1989); Sastri (2011)). İnhibitörler metalin bulunduğu ortam çözeltisine düşük oranlarda katılabileceği gibi boya içerisine katılarak da uygulanabilmektedir (Davis, 2000). İnhibitörler organik veya inorganik kökenlidir. İnorganik olanlardan bazıları kromatlar, nitritler, silikatlar, karbonatlar, fosfatlar ve arsenatlardır. Organik olanların sayısı çok daha fazladır. Bunlar aminler, heterosiklik nitrojen bileşikleri, kükürt bileşikleri (tiyoeterler, tiyoalkoller, tiyoamitler, tiyoüre ve hidrazin vb.), bazı doğal bileşikler (yapıştırıcı veya proteinler vb.) olarak sayılabilir (Davis, 2000). Koruma mekanizmasına göre inhibitörler şu şekildedir (Sastri (2011), (Aydın ve Çizmecioğlu (2013)):

- Anodik inhibitörler: Metal yüzeyindeki anodik bölgeleri kaplayarak koruma sağlarken ortamda kritik değerin altında kalması korumasız metal yüzeyinde yerel korozyona neden olabilir. Yaygın anodik inhibitörler, kromatlar, nitritler ve nitratlar gibi oksitleyici kimyasalları ve alkali fosfatlar, tungstatlar ve molibdatlar gibi oksitleyici olmayan kimyasalları içerir. Oksitleyici olmayan kimyasalların etkili olması için ortamda oksijen gibi oksitleyici bileşenler olması gerekir (Davis, 2000). Anodik inhibitöreler pH 6,5-10 aralığında etkilidir (Sastri, 2011).

- Katodik inhibitörler: Metalin elektrokimyasal pil içerisinde indirgenme reaksiyon hızını yavaşlatarak korozyon önlenir (Davis, 2000). Katodik inhibitörler çinkodan ve antimon, manganez, magnezyum ve nikel tuzları olarak sayılabilir. Anodik inhibitörlere göre daha az etkilidirler (Aydın ve Çizmecioğlu, 2013).

- Karışık tip inhibitörler (Organik inhibitörler): Metal yüzeyinde hem anodik hem de katodik bölgede koruyucu bir tabaka oluşturlar. Örneğin; amino, karboksil veya fosfonat gibi organik bileşikler karışık tip inhibitörlerdir (Sastri, 2011). Organik inhibitörler betonun geçirimliliğini azaltırlar (Aydın ve Çizmecioğlu, 2013).

Anodik ve katodik inhibitör kullanımı donatı korozyonu önlemek için yaygın tercih edilen bir yöntemdir (Ahmad, 2006). Donatı korozyonu için diğer yöntemlere göre uygulanması daha kolay ve ucuz olduğundan alternatif olarak tercih edilebilir. Betonda uygulanması şu şekillerde olabilir: taze beton karışımına eklenmesi, sertleşmiş betona sonradan uygulanması, onarım harçlarına katılması ve onarımda açığa çıkan donatılara sürülmesi (Söylev and Richardson, 2008). Donatı korozyonun önlenmesi kullanılan anodik inhibitörlere örnek olarak kalsiyum nitrit, benzoatlar, molibdatlar, kromatlar (kanserojen olduğundan kullanımı yasaklanmıştır) ve 
ortofosfatlar, katodik inhibitörlere örnek olarak fosfatlar, karbonatlar, polifosfatlar ve silikatlar verilebilir. Korozyona karşı koruyucu olarak katılan bu kimyasalların beton özelliklerine etkisini De Schutter ve Lou (2004) deneysel olarak incelemişlerdir. Yaptıkları çalışmada dört farklı korozyon inhibitörünün taze beton ve sertleşmiş beton üzerindeki etkilerini incelemişlerdir. İnhibitör olarak kalsiyum nitrat, amino ve ester bazlı organik inhibitör, aminoalkol ve kütleye süzülen (migrating) inhibitör kullanılmıştır. Üretilen betonlarda bağlayıcı olarak Portland çimentosu ve yüksek firın cüruflu çimento kullanılmıştır. Çalışma sonucunda kullanılan korozyon inhibitörlerinin beton özelliklerine büyük oranda etki etmediği ancak kalsiyum nitrat katkının diğerlerinden farklı olarak erken dönem basınç dayanımında artış sağladığı belirlenmiştir. Söylev ve arkadaşları (2007) yaptıkları çalışmada sertleşmiş beton yüzeyine sürülen aminoalkol bazlı organik inhibitörün beton özellikleri üzerine etkilerini incelemişlerdir. Beton numuneler serleştikten sonra inhibitör beton yüzeye uygulanmıştır. Yapılan deneysel çalışmalar sonucunda yüzeysel uygulanan inhibitörün betonun mekanik özelliklerine (basınç dayanımı, çekme dayanımı ve donatı-beton aderansı) bir etkisi olmadığ 1 belirlenmiştir. Ayrıca inhibitörün betondaki yüzeysel olarak gözenekleri tıkayarak betonun geçirgenliği, su emilimi ve kuruma rötresi ve donmaçözünmede kütle kaybını azalttı̆̆ belirlenmiştir.

Günümüzde yaygın kullanılan korozyon inhibitörlerine alternatif olarak "yeşil korozyon inhibitörleri" üzerine çalışmalar yapılmaktadır. Yeşil, sürdürülebilir ve çevre dostu alternatif korozyon inhibitörleri çeşitli bitkilerin yaprak, tohum, kabuk, çiçek, kök ve hatta bitkinin tamamından elde edilebilmektedir (Alrefaee ve ark. ,2021). Ayrıca süt ürünleri içerisinde bulunan kazein (Zomorodian ve ark., 2021), kitosan (Zhao ve ark., 2020), arı poleni ekstraktı (Ahmed ve Zhank, 2020) gibi birçok malzemenin değişik metaller üzerinde etkili yeşil inhibitörler olarak kullanılabileceği son zamanlarda yapılan çalışmalarla ortaya koyulmuştur.

Koruyucu kaplama yapılması korozyona karşı uygulanan başlıca yöntemlerden birisidir. Metalin korozyon direnci ana metalden daha yüksek metalik (galvanizleme vb.), organik (epoksi, vinil vb.) veya inorganik (emaye, beton kaplama vb.) kaplamalarla kaplanması yoluyla koruma sağlanır. Betonarme sistemde donatının korozyonun önlenmesi için inhibitörler, çinko kaplamalar veya ince organik kaplamalar kullanılabilir. Donatı çeliklerinde sıklıkla kullanılan organik kaplamalar poliüretan, akrilik ve klor kauçuk kaplamalardır (Popov, 2015).

Metaller korozyona karşı inorganik kaplama olan beton ile kaplanabilir. Beton sağladığ1 alkalin ortam ile korozyon oluşmasını engeller. Sadece yapılarda değil yer altı boru sistemlerinde de dökme demir ya da çelik borular içten ve dıştan beton ile kaplanarak korunabilir (NACE, 1984). Korozyona karşı koruyucu olabilmesi için beton uygun nitelikte olmalıdır. Betonun kalitesini etkiyen önemli etmenlerden birisi betonun hacimce yaklaşık \%70-80'nini oluşturan agregalardır. Agregalar ocak kaynaklı, dere veya deniz kökenli olabilir. Deniz kökenli agregalarda kavkı ve tuz sorun oluşturur. Bu nedenle deniz agregası kullanılmadan önce mutlaka elenmiş ve yıkanmış olmalıdır. Ayrıca agregaların organik kirleticiler içermemesi, sınır değerleri aşacak sülfat içermemesi ve alkali agrega reaksiyonuna neden olan türlerinin beton karışımında tercih edilmemesi gerekir. Beton karışımında su/çimento betonun geçirimsizliğini etkiler. Düşük su/çimento oranı kalıba yerleştirilirken yeterli sıkıştırma yapılmadığında yeterli ve beklenen nitelikte bir geçirimsizlik sağlamaz. Daha düşük su/çimento oranı ve geçirimsizlik istendiğinde süper akışkanlaştırıcı katkılar kullanılabilir. Puzolan katkılarda (uçucu kül, silis dumanı, yüksek firın cürufu vb.) betonun içindeki serbest kireci bağlayıp kalsiyum-silikat-hidrat ürünler oluşturup, boşlukları doldurur ve geçirimsizliği sağlar (Delikanlı, 2001). İyi ve kaliteli bir betonda paspayı yeterli kalınlıkta ve sürekli olması gerekir. Paspayında herhangi bir hasar çatlak olması durumunda donatı korozyonu başlayacak veya hızlanacaktır. Betonarme içerisinde donatı korozyondan korunması için alınması gereken önlemler şu şekilde özetlenebilir:

- Beton yapımı sırasında geçirimliliği azaltıcı önlemler alınması,

- Donatının galvanize (çinko ile kaplama) edilmesi, epoksi ile boyanması veya akrilik lateksle kaplanmas1,

- Beton yüzeylerinin geçirimsiz bir malzeme ile kaplanması 
- Beton içine inhibitör katılması

- Katodik koruma uygulanması (Yalçın ve Koç, 1997).

Donatı korozyonu için alınabilecek önlemlerin avantaj ve dezavantajları Tablo 3'te verilmiştir.

Tablo 3. Donatı korozyonu için alınabilecek önlemlerin avantaj ve dezavantajları (ElReedy, 2008)

\begin{tabular}{|l|c|c|}
\hline \multicolumn{1}{|c|}{ Yöntem } & Avantajı & Dezavantajı \\
\hline Paspayını arttırmak & Maliyeti arttırmaz & Rötre çatlağı riski artar \\
\hline Geçirimsiz beton üretmek & $\begin{array}{c}\text { Tasarıma bağlı olarak avantajları } \\
\text { değişiklik gösterir }\end{array}$ & $\begin{array}{c}\text { Üretiminde katkılar kullanılır ve } \\
\text { iyi kürlenmesi gerekir }\end{array}$ \\
\hline Su geçirimsiz örtüler & Teknolojisi çok iyi biliniyor & Hasar oluşabilir \\
\hline $\begin{array}{l}\text { Donatıların epoksi ile } \\
\text { kaplanması }\end{array}$ & $\begin{array}{c}\text { Teknolojisi iyi biliniyor } \\
\text { Çok bakım gerektirmez }\end{array}$ & $\begin{array}{c}\text { Belirli hava koşullarında kalite } \\
\text { kontrol problemi }\end{array}$ \\
\hline Galvanizli çelik & Kolay kullanım & $\begin{array}{c}\text { Galvanize edilmemiş çelikle } \\
\text { temasında kolaylıkla hasar oluşur }\end{array}$ \\
\hline Paslanmaz çelik & Mükemmel korozyon direnci & Yüksek maliyet \\
\hline Korozyon inhibitörleri & Uygulaması kolay* & Bazı türleri çevreye zararlı* \\
\hline Katodik koruma & $\begin{array}{c}\text { Teknolojisi iyi biliniyor } \\
\text { Bitanyum anotlu uygulaması uzun } \\
\text { ömürlü }\end{array}$ & (E)kli \\
\hline (El-Reedy, 2008) kaynağından alınmıştır. (*) işaretli yerler revize edilmiştir.
\end{tabular}

\section{SONUÇ}

Mimari yapılarımızda cephe ve çatı kaplamasında, taşıyıcı sistemde, süslemelerde, korkuluklarda ve birleşim elemanları gibi birçok yerde demirli ve demirsiz metaller kullanılmaktadır. Ayrıca betonarme içerisinde donatı elemanı olarak az karbon içeren donatı çeliği kullanılmaktadır. Korozyon genelde demirin paslanması olarak bilinse de demirli ve demirsiz çoğu metali etkilemektedir. Yapılan araştırmalar ise korozyonunun büyük oranda önlenebilir olduğunu göstermektedir. Yapılarımızda korozyonun önlenmesi için korozyon mekanizmasının iyi anlaşılması ve gerekli önlemlerin alınması gerekmektedir. Korozyon hasarı oluşmadan henüz tasarım aşamasında ortam şartlarına dikkat edilerek, uygun malzeme seçimi ve doğru detay tasarımıyla korozyonun önüne geçilebilir. Özellikle betonarme sistemlerde bazı durumlarda korozyonun oluşması önlemiş olsa dahi gerekli bakım ve onarım yapılmadığında uzun dönemde korozyonun kaçınılmaz olacağı açıktır. Yapı malzemelerinin kendilerinden beklenen özellikleri kaybetmeden yapı ömrü boyunca sürdürebilmelerini sağlamak için yapıların bakım ve onarımının zamanında yapılması gerekir. Böylece korozyon olayının yavaş gelişimi nedeniyle göz ardı edilen yapı hasarlarının ve malzeme kayıplarının önüne geçilebilir.

\section{ÇIKAR ÇATIŞMASI}

Yazar, bilinen herhangi bir çıar çatışması veya herhangi bir kurum/kuruluş ya da kişi ile ortak çıkar bulunmadı̆̆ını onaylamaktadırlar.

\section{YAZAR KATKISI}

Nazife Özer çalışmanın her aşamasında \%100 katkı sağlamıştır. 


\section{KAYNAKLAR}

1. Ahmad, Z. (2006) Materials and Environments, Principles of Corrosion Engineering and Corrosion Control, Butterworth-Heinemann, ISBN 9780750659246, doi: 10.1016/B978075065924-6/50005-2.

2. Aköz F. ve Çakır Ö. (2014) Betonarme Korozyonu, Hazır Beton Dergisi, Temmuz-Ağustos Say1s1, Sayfa 71-85.

3. Aydın Ö. ve Çizmecioğlu Z. (2013) Beton Yapılarda İnhibitör Kullanımının Korozyon Önlemedeki Etkinliğinin Değerlendirilmesi, Mühendislik ve Fen Bilimleri Dergisi Sigma 5, syf 129-137.

4. Bentur, A., Berke, N., \& Diamond, S. (2011) Steel corrosion in concrete : Fundamentals and civil engineering practice. ProQuest Ebook Central.

5. Broomfield, J. P. (1997). Corrosion of steel in concrete : understanding, investigation, and repair. E \& FN Spon.

6. Cicek, V, Al-Numan B. (2012) Corrosion Chemistry, Hoboken : Wiley-Scrivener. . eBook.

7. Çakır, A. F. (2013) Korozyon ekonomisi ve demir çelik ürünlerinin korozyonu, Galvaniz Dünyası, Genel Galvanizciler Derneği Galder İktisadi İşletmesi Yayın Organı, Sayı/12, İstanbul.

8. Çakır, A. F. (2016) Korozyon: Insanlı İçin Stratejik Öneme Sahip Tabii Bir Olay, Teknik Yazı, Türk Mühendis Ve Mimar Odaları Birliği Metalurji Ve Malzeme Mühendisleri Odası, Metalurji Sayı:179.

9. Davis, J. R. (2000) Corrosion : Understanding the Basics, A S M International, ProQuest Ebook Central.

10. De Schutter G., ve Lou L. (2004) Effect of corrosion inhibiting admixtures on concrete properties, Construction and Building Materials Volume 18, Issue 7, Pages 483-489.

11. Delikanlı F. (2001) Donatılı Betonda Korozyon Hasarı ve Giderilme Yolları, İstanbul Teknik Üniversitesi Fen Bilimleri Enstitüsü, Yüksek Lisans Tezi, İstanbul.

12. El-Reedy, M. A. (2008). Steel-reinforced concrete structures. [electronic resource]: assessment and repair of corrosion. CRC Press.

13. Fontana, M. G., \& Greene, N. D. (1978). Corrosion engineering. McGraw-Hill.

14. Herzog, T., Krippner, R., \& Lang, W. (2017). Facade construction manual. Retrieved from http://search.ebscohost.com/login.aspx?direct=true \&db=cat01696a\&AN=itu.b2877316\&lan $\mathrm{g}=$ tr\&site $=$ eds-live

15. http://www.kasso.com.tr/projeler/raif-dinckok-kultur-merkezi.html, Erişim Tarihi: 01 Şubat 2021, Konu: Eskitilmiş Çelik (Korten) Perfore Düz Metal Levha.

16. http://www.stevenholl.com/projects/sarphatistraat-offices? , Erişim Tarihi: 01 Şubat 2021, Konu: Patinalı Perfore Baklr Düz Metal Levha Kaplama.

17. https://www.archipelontwerpers.nl/en/projects/gown-architectural-transformation-city-thehague-architect-architectural-office/, Erişim Tarihi: 01 Şubat 2021, Konu: Zirkonyum nitrat kaplı paslanmaz çelik tel örgü.

18. https://www.graux-baeyens.be/gba-projects/recent/house-vdv/, Erişim Tarihi: 01 Şubat 2021, Konu: Bakır Levha Kaplama. 
Özer N.: Yapı Malzemelerinde Korozyon ve Korozyondan Korunma Yöntemleri

19. https://www.kme.com/copper-division/architecture/new-projects/brass/museum-of-art/, Erişim Tarihi: 01 Şubat 2021, Konu: Profillendirilmiş pirinç levha.

20. https://www.vmzinc.com/, Erişim Tarihi: 01 Şubat 2021, Konu: Polietilen dolgulu çinko kompozit levha.

21. Hunkeler, H (2005) 1-Corrosion in reinforced concrete: processes and mechanisms, Editor(s): Hans Böhni, In Woodhead Publishing Series in Civil and Structural Engineering, Corrosion in Reinforced Concrete Structures, Woodhead Publishing, 2005, Pages 1-45, ISBN 9781855737686, doi: 10.1533/9781845690434.1.

22. Jones, D. A. (1996). Principles and prevention of corrosion (Second edition.). Prentice Hall.

23. Kaftan M. A. (2006) Çelik Yapılarda Korozyon Oluşumu Ve Korozyondan Korunma Yöntemlerinin Maliyet Açısından Karşılaştırılması, Pamukkale Üniversitesi Fen Bilimleri Enstitüsü, Yüksek Lisans Tezi, Denizli.

24. Kocataşkın F.(1979) Yapı Malzemesi Bilimi, İstanbul.

25. NACE (1984), Corrosion basics: an introduction, National Association of Corrosion Engineers.

26. NACE International (2016) International Measures of Prevention, Application, and Economics of Corrosion Tecnologies Study Report, USA. Retraived from http://impact.nace.org/documents/Nace-International-Report.pdf

27. Nadzri, N.I. ve Amin, N.M. (2019) A Review of Cathodic Protection in Repairing Reinforced Concrete Structures, Journal of Mechanical Engineering Vol 16(2), 183-198.

28. Onaran, K. (2014) Malzeme Bilimi, Bilim Teknik Yayınevi, 13. Bask1, İstanbul.

29. Popov, B.N. (2015) Corrosion Engeenering Prensiple and Solved Problems, Elsevier, ISBN 9780444627223 , eBook.

30. Revie, R. W., \& Uhlig, H. H. (2008). Corrosion and corrosion control : an introduction to corrosion science and engineering (4th ed.). J. Wiley

31. Roberge P.R. (2012) Handbook of Corrosion Engineering, Second Edition, The Mc-GrawHill Companies, USA.

32. Sastri, V. S. (2011). Green corrosion inhibitors : theory and practice. Wiley.

33. Söyle, T.A. and Richardson, M.G (2008) Corrosion inhibitors for steel in concrete: State-ofthe-art report, Construction and Building Materials 22 (2008) 609-622.

34. Söylev T.A., McNally C., Richardson M. G. (2007) The effect of a new generation surfaceapplied organicinhibitor on concrete properties, Cement \& Concrete Composites 29, 357-364

35. Tuutti, K. (1982) Corrosion of steel in concrete, Swedish Cement and Concrete Research Institute, Stocholm.

36. Yalçın H. ve Koç T. (1991) Demir ve Çelik Yapıların Korozyonu ve Katodik Koruması, İller Bankası Genel Müdürlüğü, Ankara.

37. Yalçın H. ve Koç T. (1997) Mühendisler Iç̧in Korozyon, Kimya Mühendisler Odası, Ankara.

38. Zakar, L. ve Eyüpgiller K.E. (2018) Mimari restorasyon koruma ve yöntemleri, İstanbul. 